\section{Dominance behavior of rats under survival motivation}

\author{
EDWARD T. UYENO* \\ Stanford Research Institute, Menlo Park, Calif. 94025
}

An air-deprivation technique was used to investigate the effects of different degrees of hypoxia on the dominance behavior of rats in a competition to escape from the underwater tube. The animals, subjected to a higher degree of hypoxia were more dominant than their matched opponents, indicating that the higher degree of hypoxia had increased their survival motivation.

Air deprivation as a motivational technique in which animals are detained for varying periods in an underwater startbox, has been used by Broadhurst (1957) to confirm the Yerkes-Dodson law (1908) and "Crespi effect." In the present experiment, the technique was adopted to investigate the behavior of rats striving to exit from an underwater tube.

\section{APPARATUS}

The apparatus consisted of a clear plastic tube, $1 \mathrm{~m} 20 \mathrm{~cm}$ long and $5 \mathrm{~cm}$ in diam, placed horizontally in a tank $(2 \mathrm{~m} \times 40 \mathrm{~cm} \times 15 \mathrm{~cm}$ ) and submerged in $10 \mathrm{~cm}$ of water at $23^{\circ} \mathrm{C}$ (Uyeno \& White, 1967, 1968). A detachable startbox, also made of a similar tube, was used at each end of the swim tube. Small holes all around the start tubes permitted easy submersion. Rats weighing $180-220 \mathrm{~g}$ could swim through it, but could not turn around in it or pass another rat swimming in the opposite direction.

SUBJECTS

Forty male rats of the Wistar strain were housed individually and maintained on a feeding schedule so that their weights remained approximately constant at $200 \mathrm{~g}$.

\section{PROCEDURE}

In the first pretraining trial the animals were placed one at a time in a startbox and were partly submerged at one end of a half-submerged $68-\mathrm{cm}$ tube. They were allowed to traverse through the tube and escape at the

\footnotetext{
* The author thanks Homer Tong for his
} technical assistance. other end but were not allowed to escape from the starting point. On the second pretraining trial they were completely submerged and forced to swim through the $68-\mathrm{cm}$ tube. On all trials after the second pretraining trial, the animals were fully submerged and forced to swim through the longer tube $(1 \mathrm{~m} 20 \mathrm{~cm})$ in order to escape. On the third pretraining trial, the time taken to swim the long tube was measured in seconds with a stopwatch. On the basis of this swimming time, the 40 males were matched and assigned to two groups of equal size. The first group swam from the right to the left end of the tube during the 12 training trials, whereas the second group swam from left to right. Two trials were given daily, allowing $4 \mathrm{~h}$ between the first and second daily trials. The time taken to swim through the tube was recorded. On the basis of the swimming time on the last four training trials, the animals in each group were ranked within each group. Each male in Group 1 was paired with a male with a similar rank in Group 2. In each pair, one of the members was considered as an experimental animal and deprived of air for a substantially longer period than the control animal. DOMINANCE TEST

A control animal was placed in a startbox at one end of the tube and partly submerged for $9.5 \mathrm{sec}$, allowing the animal an access to air. Simultaneously, an experimental animal (i.e., its matched opponent) was placed in another startbox at the opposite end of the tube and completely submerged for $10 \mathrm{sec}$.
After 9.5 sec the startbox with the control animal was completely submerged and the startdoor was immediately lifted to allow the animal to swim into the main tube. Half a second later the startdoor of the box containing the experimental animal was lifted to allow the animal to swim into the tube. (Previous work with other rats had indicated that if an experimental animal was allowed to enter the tube $0.5 \mathrm{sec}$ after the entrance of its opponent, the pair would meet approximately at the center of the tube). As they approached each other, the animal that forced its opponent to retreat to the opponent's starting point was scored as dominant.

\section{RESULTS}

Seventeen experimental animals and only two control animals were dominant. According to the binomial test for small samples (Siegel, 1956, Table D, p. 250), this difference is statistically significant $(\mathrm{X}=2, \mathrm{p}<.01$, $\mathrm{N}=20$ pairs). Thus, the experiment has shown that animals subjected to a higher degree of hypoxia than their matched opponents are more dominant, indicating that an increase in the air-deprivation period has intensified their survival motivation. The results of the present study are consistent with those of Broadhurst (1957), who also found that the air deprivation increased the motivation of the rats.

\section{REFE RENCES}

BROADHURST, P. L. Air deprivation as a motivational technique in the rat, and its application to the problem of emotionality as a determinant of drive. British Psychological Society Bulletin, $1957,32,23$.

SIEGEL, S. Nonparametric statistics for the behavioral sciences. New York: McGraw-Hill, 1956 .

UYENO, E. T., \& WHITE, M. Social isolation and dominance behavior. Journal of Comparative \& Physiological Psychology, 1967, 63, 157-159.

UYENO, E. T., \& WHITE, M. Sex and dominance behavior in the rat. Psychonomic Science, 1968, 13, 192.

YERKES, R. M., \& DODSON, J. D. Relation of strength of stimulus to rapidity of habit formation. Jourmal of Comparative \& Neurological Psychology, $1908,18,459-482$. 